\title{
2-Phenylchroman-4-one as Synthone in Synthesis of \\ New Five and Six Membered Rings Heterocyclic Compounds
}

Moneera Y. Raoof

Department of Chemistry

College of science

University of Mosul, Iraq
Shakir M. Saied

Department of Pharmacy

Institute of Technical Mosul

Foundation of Technical Education

\section{Moayed S. AL. Gawady \\ Department of Chemistry / College of science \\ University of Mosul, Iraq}

Received
$29 / 06 / 2010$
Accepted

$06 / 10 / 2010$

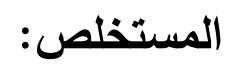

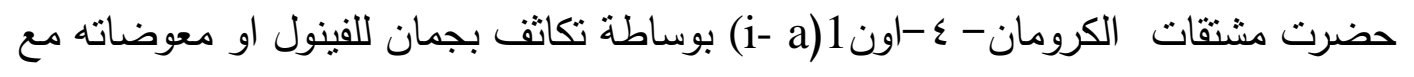

حامض السيناميك باستخدام متعدد حامض الفوسفريك .فوعلت هذه المشتقات مع الهيدرازين

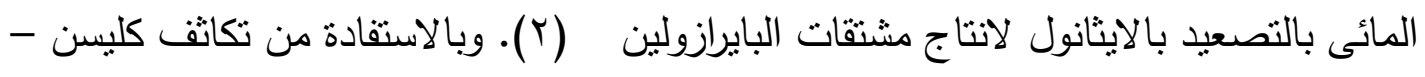

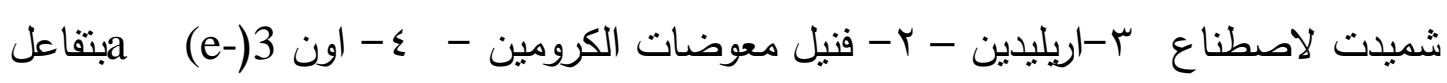

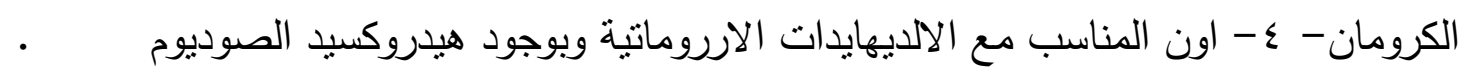

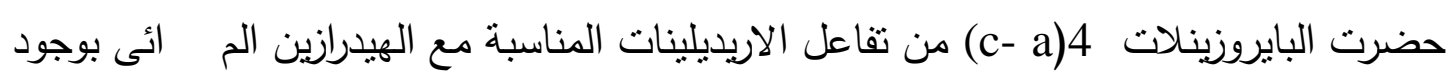

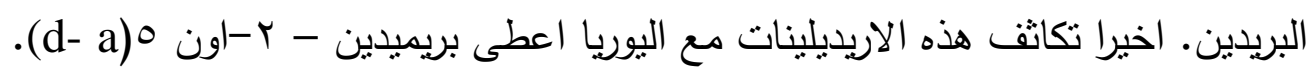

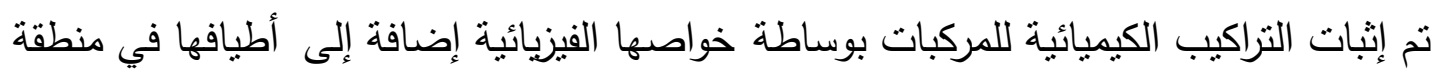
الأشعة تحت الحمراء وفوق البنفسجية.

Keywords: Chroman-4-one, cinnamic acid, pyrazoline, pyrimidin-2-ones

\section{Abstract:}

Chroman-4-one derivatives 1(a-i) were prepared by Pechman condensation of phenol or its substitutions with cinnamic acid by using polyphosphoric acid. These derivatives were reacted with hydrazine hydrate in refluxing ethanol to yield pyrazoline derivatives (2). The utility 
of the Claisen-Schmidt condensation in the synthesis of -3-arylidenesubstituted 2-phenyl chroman-4-one 3(a-e) by reaction of proper 4chromanone (1) with aromatic aldehydes in presence of $\mathrm{KOH}$. Pyrazolines 4(a-c) were synthesized by the reaction of proper arylidenes 2 with hydrazine hydrate in presence of pyridine. Finally, the condensation of arylidines with urea gave pyrimidin-2-ones 5(a-d).

The structures of these compounds were confirmed by their physical properties in addition to the IR and UV Spectra.

\section{Introduction:}

Chromans containing pyrazoline or pyrimidines were synthesized owing to their biological activities as anticoagulant, antibacterial, antielminthic, hypothermal and vasodilatory [1-3]. Recently an increasing attention has been focused on these ring system[4].

Also, a potential useful structure - activity relationship appeared to exist with pyrazolines nuclei[5-6], which were important nitrogencontaining heterocyclic compounds owing to their useful bioactivities such as invitro antiamoebic activity [7].

The reaction of carboxylic acid such as tiglic acid and crotonic acid with substituted phenols as Pechman like action using polyphosphoric acid was previously reported [8].

The chromanone moieties formed by this reaction was a good examples of $\alpha, \beta$-unsaturated ketones (chalcones) and they were especially important starting materials or intermediates for the synthesis of naturally occurring flavonoids and various nitrogen-containing heterocyclic compounds [9].

While these compounds were reacted with hydrazine hydrate in hot pyridine to yield pyrazolines derivatives [10], they reacted with urea or thiourea to afforded pyrimidines derivatives[11].

It was hoped that a new class of 2-phenylchroman-4-one derivatives and of general formula 3-5 that contained combined elements of both chromanone and pyrazoline or pyrimidines derivatives might show enhanced biological properties.

As part of continuous program directed toward the synthesis of important heterocyclic compounds, oxygenous and nitrogenous five and six membered ring [11-12]. It was become of interest to investigate preparative routs to synthesis of 2-Phenylchroman-4-one 1(a-i) to use it as synthon in synthesis of the title compounds.

\section{Experimental:}

All melting points were determined on a Gallen Kamp and Electrothermal 1 A9300 Digital-Series (1998) apparatus and were uncorrected. The IR - spectra $\left(v \operatorname{max~cm}{ }^{-1} \mathrm{KBr}\right.$ Disc) were recorded on Perkin - Elmer 590B Spectrophotometer. UV-On Shimadzu UV-160 us in $\mathrm{CHCl}_{3}$ as solvent 
substituted 2-phenyl chroman-4-one 1(a-i): [8]

Polyphosphoric acid (40gm) was added to a mixture of proper phenol (25mmole) and cinnamic acid (3.7 gm, $25 \mathrm{mmole})$ at room temperature. The mixture was stirred and heated on a steam bath at 70-80 ${ }^{\mathrm{O}} \mathrm{C}$ for $1-5 \mathrm{hrs}$. The mixture was poured into ice water. The solid which separated out was filtered off, washed with water, dried and recrystallized from the suitable solvent to give compounds $1(\mathrm{a}-\mathrm{e})$.

Compounds 1(f-i) which gave a gummy products were extracted by benzene, washed with water, dried over $\mathrm{MgSO}_{4}$. Evaporation under vacuum and the residual solids were recrystallized from the suitable solvent. Physical and spectral data were listed in Table (1).

Table (1) : Physical and spectral data of substituted 2-phenyl chroman-4-one 1(a-i)<smiles>O=C1CC(c2ccccc2)Oc2ccccc21</smiles>

\begin{tabular}{|c|c|c|c|c|c|c|c|}
\hline \multirow{2}{*}{$\begin{array}{l}\text { Comp. } \\
\text { No. } 1\end{array}$} & \multirow[t]{2}{*}{$\mathrm{R}$} & \multirow{2}{*}{$\stackrel{\text { M.P. }}{{ }^{\circ} \mathrm{C}}$} & \multirow{2}{*}{$\begin{array}{l}\text { Yield } \\
\%\end{array}$} & \multirow[t]{2}{*}{ Colour } & \multirow{2}{*}{$\begin{array}{c}\text { Solvent of } \\
\text { crystallization }\end{array}$} & $\begin{array}{c}\mathrm{IR}, \mathrm{KBr} \text { (disc), } \\
\mathrm{Cm}^{-1}\end{array}$ & \multirow{2}{*}{$\begin{array}{c}\mathbf{U v} \\
\lambda \max \\
(\mathrm{nm}) \\
\mathrm{CHCl}_{3}\end{array}$} \\
\hline & & & & & & $\mathrm{C}=\mathrm{O}$ & \\
\hline $\mathrm{a}$ & $\mathrm{H}$ & $\begin{array}{l}158 \\
60-\end{array}$ & 30 & Orange & $\begin{array}{c}\text { Aqueous } \\
\text { ethanol }\end{array}$ & 1645 & 322 \\
\hline $\mathrm{b}$ & 7- $\mathrm{NO}_{2}$ & $\begin{array}{l}108 \\
-10\end{array}$ & 30 & Pale yellow & $\begin{array}{l}\text { Aqueous } \\
\text { methanol }\end{array}$ & 1689 & 300 \\
\hline $\mathrm{c}$ & $8-\mathrm{Br}$ & $\begin{array}{l}110 \\
12-\end{array}$ & 30 & White & $\begin{array}{l}\text { Aqueous } \\
\text { methanol }\end{array}$ & 1685 & 310 \\
\hline d & 6-Br & $\begin{array}{c}106 \\
-108 \\
\end{array}$ & 77 & Pale yellow & $\begin{array}{l}\text { Aqueous } \\
\text { methanol }\end{array}$ & 1635 & 316 \\
\hline $\mathrm{e}$ & 6- $\mathrm{CH}_{3} \mathrm{O}$ & $\begin{array}{c}60 \\
-62\end{array}$ & 33 & Yellow & $\begin{array}{l}\text { Aqueous } \\
\text { methanol }\end{array}$ & 1635 & 286 \\
\hline $\mathrm{f}$ & $6 \mathrm{Cl}$ & $\begin{array}{c}101- \\
02 \\
\end{array}$ & 93 & White & Ethanol & 1635 & 306 \\
\hline $\mathrm{g}$ & $6,8) \mathrm{CH}_{3}(2$ & $\begin{array}{c}62 \\
-64 \\
\end{array}$ & 32 & Yellow & Ethanol & 1635 & 316 \\
\hline $\mathrm{h}$ & $6,7) \mathrm{CH}_{3}(2$ & $\begin{array}{c}65 \\
-67 \\
\end{array}$ & 37 & Yellow & Ethanol & 1639 & 310 \\
\hline $\mathrm{i}$ & $5,7) \mathrm{CH}_{3}(2$ & $\begin{array}{c}68- \\
70 \\
\end{array}$ & 76 & Yellow & Diethyl ether & 1614 & 272 \\
\hline
\end{tabular}

\section{3-aryl-5-phenyl-2-pyrazolines 2(a-g): [8]}

Equimolecular amounts of proper compound (1) (0.9mmole)in 15$20 \mathrm{ml}$ ethanol and hydrazine hydrate was refluxed for 48hours .

The mixture was gradually poured into crushed ice.The solid was filtered washed with cold water, dried and crystallized from ethanol to afford the title compounds. Physical and spectral data were listed in Table (2). 
Table (2) : Physical and spectral data of 3-aryl-5-phenyl-2-pyrazolines 2(a-g)

\begin{tabular}{|c|c|c|c|c|c|c|c|}
\hline \multirow{2}{*}{$\begin{array}{c}\text { Comp. } \\
\text { No. } 2\end{array}$} & \multirow{2}{*}{$\mathrm{R}$} & \multirow{2}{*}{$\stackrel{\text { M.P. }}{{ }^{\mathrm{O}} \mathrm{C}}$} & \multirow{2}{*}{$\begin{array}{c}\text { Yield } \\
\%\end{array}$} & \multirow{2}{*}{ Colour } & \multicolumn{2}{|c|}{$\mathrm{IR}, \mathrm{KBr}$ (disc), $\mathrm{Cm}^{-1}$} & \multirow{2}{*}{$\begin{array}{c}\mathbf{U v} \\
\lambda \max \\
(\mathrm{nm}) \\
\mathrm{CHCl}_{3}\end{array}$} \\
\hline & & & & & $\mathrm{C}=\mathrm{N}$ & $\mathrm{NH}$ & \\
\hline $\mathrm{a}$ & $\mathrm{H}$ & $82-4$ & 44 & $\begin{array}{l}\text { Pale } \\
\text { Yellow }\end{array}$ & 1639 & 3318 & 286 \\
\hline $\mathrm{b}$ & $7-\mathrm{NO}_{2}$ & $230 *$ & 43 & Brown & 1637 & 3236 & 262 \\
\hline $\mathrm{c}$ & $8-\mathrm{Br}$ & $120 *$ & 44 & White & 1637 & 3411 & 282 \\
\hline d & $6-\mathrm{Br}$ & $97-9$ & 46 & White & 1620 & 3305 & 282 \\
\hline $\mathrm{e}$ & $6-\mathrm{CH}_{3} \mathrm{O}$ & $174-76$ & 44 & White & 1620 & 3240 & 304 \\
\hline $\mathrm{f}$ & $6,8\left(\mathrm{CH}_{3}\right)_{2}$ & $98-100$ & 42 & Brown & 1637 & 3236 & 304 \\
\hline $\mathrm{g}$ & $6,7\left(\mathrm{CH}_{3}\right)_{2}$ & $92-4$ & 44 & White & 1637 & 3233 & 284 \\
\hline
\end{tabular}

*Decomposed

\section{3-Arylidene-substituted 2-phenyl chroman-4-one 3(a-e): [11]}

To a mixture of (0-01mole) of the proper aldehyde and (0.01mole) of appropriate substituted 2-phenyl chroman-4-one 1, a solution of $(0.33 \mathrm{gm})$ of potassium hydroxide in $50 \mathrm{ml}$ ethanol was added. The reaction mixture was stirred. The reaction mixture was stirred at room temperature for 3 hours, the precipitate productwas filtered, washed with ethanol, dried and crystallized from ethanol to give compounds 3(a-e). Physical and spectral data were listed in Table (3).

Table (3) : Physical and spectral data of 3-Arylidene-substituted 2-phenyl chroman-4-one 3(a-e)<smiles>[R]c1cccc(OC/C(=C/[123I])C(=O)c2ccccc2)c1</smiles>

\begin{tabular}{|c|c|c|c|c|c|c|c|}
\hline \multirow{2}{*}{$\begin{array}{l}\text { Comp. } \\
\text { No.3 }\end{array}$} & \multirow{2}{*}{$\mathrm{R}$} & \multirow{2}{*}{$\mathrm{Ar}$} & \multirow{2}{*}{$\stackrel{\substack{\text { M.P.P. } \\
{ }^{0} \mathrm{C}}}{ }$} & \multirow{2}{*}{$\begin{array}{c}\text { Yield } \\
\%\end{array}$} & \multicolumn{2}{|c|}{$\mathrm{IR}, \mathrm{KBr}$ (disc), $\mathrm{Cm}^{-1}$} & \multirow{2}{*}{$\begin{array}{c}\mathbf{U v} \\
\lambda \max \\
(\mathrm{nm}) \\
\mathrm{CHCl}_{3}\end{array}$} \\
\hline & & & & & $\mathrm{C}=\mathrm{C}$ & $\mathrm{C}=\mathrm{O}$ & \\
\hline $\mathrm{a}$ & $7-\mathrm{NO}_{2}$ & $\mathrm{C}_{6} \mathrm{H}_{5^{-}}$ & $111-13$ & 60 & 1624 & 1680 & 290 \\
\hline $\mathrm{b}$ & $8-\mathrm{Br}$ & $\mathrm{C}_{6} \mathrm{H}_{5^{-}}$ & $118-20$ & 66 & 1619 & 1680 & 288 \\
\hline $\mathrm{c}$ & $6-\mathrm{Br}$ & $\mathrm{C}_{6} \mathrm{H}_{5^{-}}$ & $120-21$ & 50 & 1603 & 1680 & 288 \\
\hline d & $6,7\left(\mathrm{CH}_{3}\right)_{2}$ & $\begin{array}{l}2-\mathrm{Cl}- \\
\mathrm{C}_{6} \mathrm{H}_{4}- \\
\end{array}$ & $186-88$ & 62 & 1624 & 1678 & 300 \\
\hline $\mathrm{e}$ & $5,7\left(\mathrm{CH}_{3}\right)_{2}$ & $\begin{array}{l}2-\mathrm{Cl}- \\
\mathrm{C}_{6} \mathrm{H}_{4}-\end{array}$ & $\begin{array}{c}180 \\
\text { (decomposed) }\end{array}$ & 44 & 1614 & 1666 & 299 \\
\hline
\end{tabular}


3-Aryl-4-phenyl-substituted chromano[4,3-c]pyrazole 4(a-c): [11]

A mixture of proper 3-arylidene-substituted 2-phenyl chroman-4one 3(a-e) (0.01 mole) in $25 \mathrm{ml}$ ethanol, hydrazine hydrate $(0.06$ mole) and pyridine $(4 \mathrm{ml})$ was refluxed for 6 hours, cooled, concentrated under vacuum, then poured into water and acidified with acetic acid. The residue was filtered off, washed with water and crystallized from methanol to afford compounds 4(a-j). Physical and spectral data were listed in Table (4).

Table (4): Physical and spectral data of 3-Aryl-4-phenyl-substituted chromano[4,3-c]pyrazole 4(a-c)

\begin{tabular}{|c|c|c|c|c|c|c|c|}
\hline \multirow{2}{*}{$\begin{array}{c}\text { Comp. } \\
\text { No.3 }\end{array}$} & $\mathrm{R}$ & $\mathrm{Ar}$ & \multirow{2}{*}{$\begin{array}{c}\text { M.P. } \\
{ }^{\circ} \mathrm{C}\end{array}$} & $\begin{array}{c}\text { Yield } \\
\%\end{array}$ & \multicolumn{2}{|c|}{$\mathrm{IR,} \mathrm{KBr}(\mathrm{disc}), \mathrm{Cm}^{-1}$} & \multirow{2}{*}{$\begin{array}{c}\text { Uv } \\
\text { (nm) }\end{array}$} \\
\cline { 6 - 7 } & & & & $\mathrm{C}=\mathrm{N}$ & $\mathrm{NH}$ & $\mathrm{CHCl}_{3}$ \\
\hline $\mathrm{a}$ & $6 \mathrm{Cl}$ & $2-\mathrm{ClC}_{6} \mathrm{H}_{4^{-}}$ & $\begin{array}{c}130 \\
\text { (decomposed) }\end{array}$ & 30 & 1630 & 3330 & 260 \\
\hline $\mathrm{b}$ & $6,7\left(\mathrm{CH}_{3}\right)_{2}$ & $2-\mathrm{ClC}_{6} \mathrm{H}_{4^{-}}$ & $119-21$ & 45 & 1633 & 3418 & 345 \\
\hline $\mathrm{c}$ & $5,7\left(\mathrm{CH}_{3}\right)_{2}$ & $2-\mathrm{ClC}_{6} \mathrm{H}_{4^{-}}$ & $126-30$ & 33 & 1630 & 3234 & 270 \\
\hline
\end{tabular}

\section{4-(2-Chlorophenyl)-5-phenyl-3,4,4a,5-substituted chromano[4,3-} d]pyrimidin-2-one 5(a-d): [11]

A mixture of proper 3-arylidene-substituted 2-phenyl chroman-4one 3 (0.01 mole) in $100 \mathrm{ml}$ ethanol and urea (0.6 gm, 0.01 mole) was refluxed for 24 hours, cooled, concentrated under vacuum, then poured into water and acidified with acetic acid. The precipitated product was filtered, dried and crystallized from ethanol to afford compounds 5(a-d). Physical and spectral data were listed in Table (5).

Table (5) :Physical and spectral data of 4-(substitutedphenyl)-5-phenyl-3,4,4a,5substituted chromano[4,3-d]pyrimidin-2-one 5(a-d)

\begin{tabular}{|c|c|c|c|c|c|c|c|}
\hline \multirow{2}{*}{$\begin{array}{c}\text { Comp. } \\
\text { No.3 }\end{array}$} & \multirow{2}{*}{$\mathrm{R}$} & \multirow{2}{*}{$\mathrm{Ar}$} & \multirow{2}{*}{$\stackrel{\text { M.P. }}{{ }^{\circ} \mathrm{C}}$} & \multirow{2}{*}{$\begin{array}{c}\text { Yield } \\
\%\end{array}$} & \multicolumn{2}{|c|}{$\mathrm{IR}, \mathrm{KBr}$ (disc), $\mathrm{Cm}^{-1}$} & \multirow{2}{*}{$\begin{array}{c}\mathbf{U V} \\
\lambda \max \\
(\mathrm{nm}) \\
\mathrm{CHCl}_{3}\end{array}$} \\
\hline & & & & & $\mathrm{NH}$ & $\mathrm{C}=\mathrm{O}$ & \\
\hline A & $6-\mathrm{Br}$ & $\mathrm{C}_{6} \mathrm{H}_{3}$ & $280^{*}$ & 25 & 3234 & 1671 & 278 \\
\hline B & $6 \mathrm{Cl}$ & $2 \mathrm{Cl}-\mathrm{C}_{6} \mathrm{H}_{3}$ & $260^{*}$ & 36 & 3234 & 1701 & 304 \\
\hline $\mathrm{C}$ & $5,7\left(\mathrm{CH}_{3}\right)_{2}$ & $2 \mathrm{Cl}-\mathrm{C}_{6} \mathrm{H}_{3}$ & $158-60$ & 22 & 3234 & 1566 & 304 \\
\hline $\mathrm{D}$ & $6,7\left(\mathrm{CH}_{3}\right)_{2}$ & $2 \mathrm{Cl}-\mathrm{C}_{6} \mathrm{H}_{3}$ & $140 *$ & 20 & 3334 & 1680 & 304 \\
\hline
\end{tabular}




\section{Results and discussion:}

A convenient synthesis of all new target compounds were accomplished by the route outlined in Scheme(1).<smiles>O=C(O)/C=C/c1ccccc1</smiles><smiles>[R]c1cccc(O)c1C1=NNC(c2ccccc2)C1</smiles>

Substituted2-phenyl chroman-4-one $1(\mathbf{a}-\mathbf{e})$

ArCHO Alcoholic KOH $\bigvee$ 3-aryl-5-phenyl2-pyrazolines 2(a-g) )<smiles></smiles>

3-Arylidene-substitutrd -2-phenyl chroman-4-one<smiles>[R]c1cccc(OC(CN)c2ccccc2)c1-c1ccccc1</smiles>

3-(2-Chlorophenyl)-4-phenylsubstituted chromeno $[4,3-c]$ pyrazole $4(a-c)$

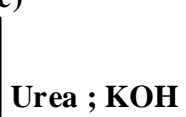<smiles>[R]c1cccc(C)c1C1=NC(=O)NC([Al])C1C(Oc1ccccc1)c1ccccc1</smiles>

4-(2-Chlorophenyl)-5-phenyl-3,4,4a,5substituted chromeno[4,3-d]pyrimidin-2-one 5(a-d) 
4-Chromanone derivatives 1(a-i) served as key intermediates for the synthesis of the target heterocyclic compounds (2-5) [8-11].

These new compounds were prepared by Pechman condensation of phenol or its substitutions with cinnamic acid by using polyphosphoric acid[9].

A special attention has been given as a part of efforts to develop practical synthesis of compounds 1(f-i) duo to their gummy products by using benzene to extract them.

4-Chromanone moiety reacted with hydrazine hydrate in refluxing ethanol to yield pyrazoline derivatives[11]. Consequently; the structures of these compounds were clearly established by IR and UV spectral features. The absence of carbonyl absorption bands at $1700 \mathrm{~cm}^{-1}$ confirmed the reaction of these groups with hydrazine hydrate by the suggested mechanism, Scheme 2 [11].

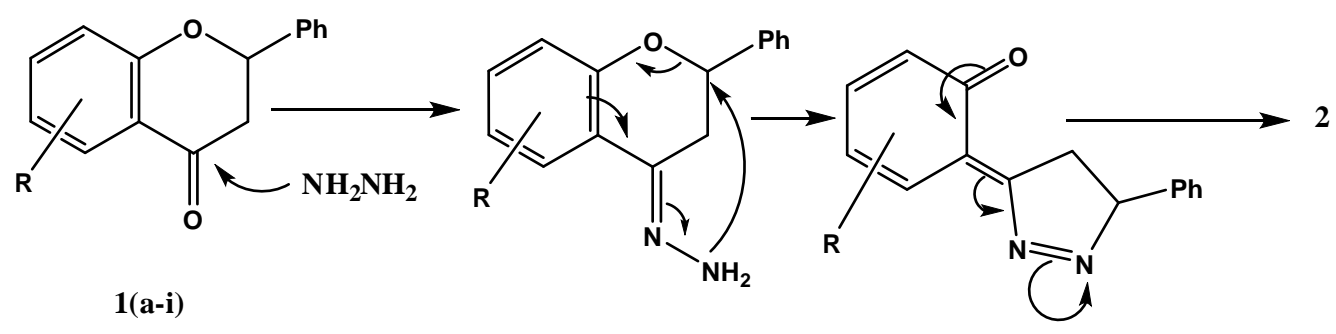

Scheme (2)

In the course of the synthetic studies on chromanone derivatives, this work demonstrated the utility of the Claisen-Schmidt condensation in the synthesis of these new Z-(3-arylidene-2-phenylsubstituted chroman-4ones 3(a-e). These compounds were prepared by condensation of proper 4-chromanone 1 with corresponding aromatic aldehydes in presence of $\mathrm{KOH}$, Scheme 3[11].

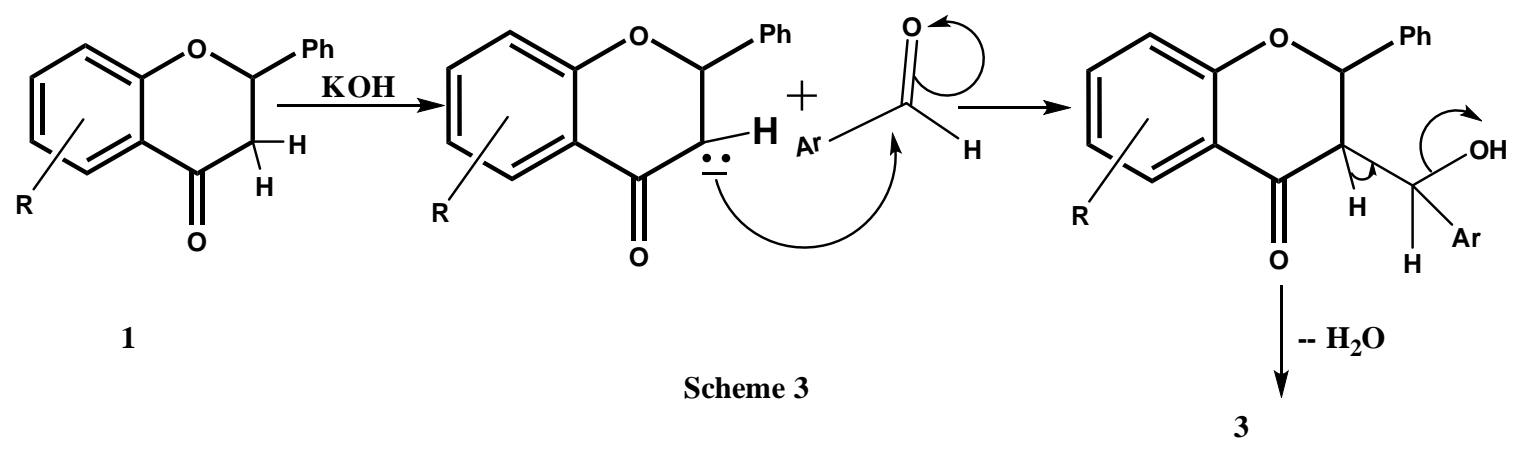

Inspection of models indicated that these compounds may adopted the strainless (Sofa) conformation in which all the atoms of heterocyclic ring, except C2 were coplanar[13-14], and performed the chair conformation[13]. Fig(1) showed the model of compound 3a which was 
selected as a representative for this serious as drawn by Chem3D with solvent accessible surface: translucent surface type and atom colors map property.

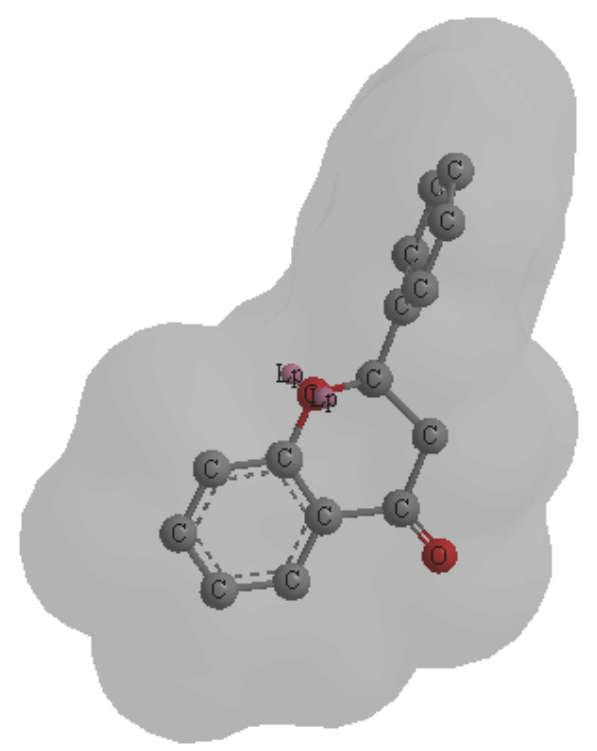

Fig. ( 1 )

Model of 3(a) as drawn by Chem3D with solvent accessible surface : translucent surface type and atom colors map property

The IR frequencies of these compounds showed the presence of conjugated carbonyl carbon at $\left(168-1666 \mathrm{~m}^{-1}\right)$ with the exocyclic double bonds $\left(1624-1600 \mathrm{~cm}^{-1}\right)$, Table 3 .

The decrease in frequency was due to the decrease of the force constant result from conjugation[11]. Finally the UV absorption between 284-305 $\mathrm{nm}$ (Table 3) showing the relationship of these structures to that of related chalcons[11].

Pyrazolines 4(a-c) were synthesized by the reaction of proper arylidenes (2) with hydrazine hydrate in presence of pyridine by nucleophilic addition on $\beta$-carbon (1,4-Michael addition). The driving force for the pyrazoline ring formation was the water elimination[11]. Scheme 4.

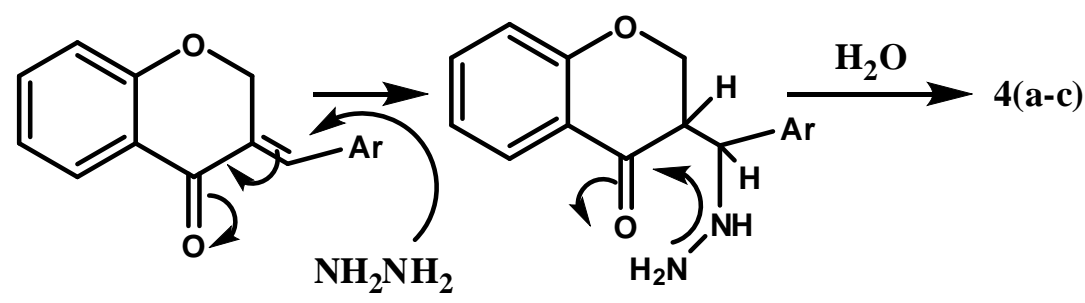

Scheme 4 
The spectra of these compounds were came in agreement with pyrazoline moiety.

The UV absorptions were in the range 260-345nm, while the IR spectrum showed the disappearing of carbonyl band and another bands at(1630-1633) of $\mathrm{C}=\mathrm{N}$ str, and (3418-3234) for $\mathrm{NH}$ str were appeared.

Finally, the condensation of these arylidines with urea gave pyrimidin-2ones 5(a-d) by the same mechanism of Michael addition.

The IR spectra of these compounds reflect a broad band in the region $1680 \mathrm{~cm}^{-1}$ for $\mathrm{C}=\mathrm{O}$ and $3334-3234 \mathrm{~cm}^{-1}$ for $\mathrm{NH}$ vibrations, Table 5 .

The UV absorptions were in the range $278-304 \mathrm{~nm}$ resemble to those published for similar compounds[11].

\section{References :}

1) Okumura, K.; Ashino, K. and Okuda, T., "Synthesis and antibacterial activity of some new fused chromenes" Yakugaku Zasshi 81, 1482, (1962) Chem. Abstr. 1962, 56, 7938.

2) El-saghier, A. M. M.; Al-afaleq, E. I.; Mouli, R. B. and Reddy, Y. D.; "Synthetic Reactions of Coumarin-3-(4-aminosulfonylCarboanlide Derivatives with Active Methylene Compounds" Ind. J. Chem. 2B, 176. (1983)

3) Khodairy, A. "Synthesis of Some New Heterocyclic Compounds from Benzopyrano [2,3-c] Pyrazol-3-one Derevatives" Synthetic Communications Vol. 31, Issue 17PP 2697 - 2712, (2001).

4) Ahmed, M. M. El-Saghier; Mahbouba, B. N.; Bahlul Kh. R.; Nabil A. S.; and Khaled M. "Synthesis and antibacterial activity of some new fused chromenes" ARKIVOC (xvi) 83-91 (2007).

5) Lévai, A.; Katalin, E. K. and Jekő, J." Synthesis of tricyclic fused pyrazolines by the reaction of 3-arylidenechromanones and 3arylidene-1-thiochromanones with hydrazine" ARKIVOC (viii) 26-39 (2007).

6) Ramalingam, K.; Thyvelikakath, G. X.; Berlin, K. D.; Chesnut, R. W.; Brown, R. A.; Durham, N. N.; Ealick, S. E.; Van der Helm, D. J. Med. Chem., 20, 847 (1977).

7) Singh, S., Bharti, N. and Mohapatra, P. "Chemistry and Biology of Synthetic and Naturally Occurring Antiamoebic Agents“, Chem. Rev., 109 (5), pp 1900-1947(2009). 
8) Ayoub, M. T.; Al-Hamdany, R. and Al-Bayati, R. I. "Synthesis of some substituted 3-aryl-5, 5-dimethyl-2-pyrazolines Journal of the Iraqi Chemical Society, 10(2), 131-40. ISSN: 0379-8321; (1985).

9) Dhar, D. N. "The Chemistry of Chalcones and Related Compounds'; Wiley-Interscience: NewYork (1981).

10) Lévai, A. "Synthesis of exocyclic $\alpha, \beta$-unsaturated ketones" ARKIVOC (vii) 15-33; (2004).

11) Saied, S. M. "Synthetic studies of important heterocyclic compounds"; (2000), PhD Thesis, Department of Chemistry, College of science; University of Mosul, Iraq(2000).

12) Shandala, M. Y. Ayoub, M. T. and Noori, M. S. "Synthesis of 5substituted 1,3,4-oxadiazoline-2-thiones and related compounds derived from diphenyl acetic acid (part ii). J. Raf. Sci, Chemistry Special Issue,1.(2002)

13) Keane, D. D.; Marathe, K. G.; Teague, P. C.; Sullivan, W. I. O.; Philbin, E. M. and Simons, R. M. "Configuration and conformation of 3-arylideneflavanones" J. Org. Chem., 35 (7), pp 2286-2290 (1970).

14) Potgieter, E. D., "Conformational Analysis of Oligomeric Profisetidins"; PhD Thesis, Department of Chemistry, Faculty of Natural and Agricultural Sciences, University of the Free State Bloemfontein, South Africa (2007). 